\title{
CENTRALNA EWIDENCJA I INFORMACJA O DZIAŁALNOŚCI GOSPODARCZEJ W ŚWIETLE NOWYCH PRZEPISÓW PRAWNYCH
}

\section{WPROWADZENIE}

Ustawa z 6 marca 2018 r. o Centralnej Ewidencji i Informacji o Działalności Gospodarczej i Punkcie Informacji dla Przedsiębiorcy ${ }^{1}$ zastapiła przepisy dotyczace Centralnej Ewidencji i Informacji o Działalności Gospodarczej (CEIDG) zawarte w rozdz. 3 ustawy z 2 lipca 2004 r. o swobodzie działalności gospodarczej ${ }^{2}$ oraz przepisy rozdz. 2 a u.s.d.g. regulujące zadania pojedynczego punktu kontaktowego.

CEIDG utworzona ustawa z 19 grudnia 2008 r. o zmianie ustawy o swobodzie działalności gospodarczej oraz o zmianie niektórych ustaw ${ }^{3}$ określiła nowe zasady oraz tryb ewidencjonowania działalności gospodarczej prowadzonej przez osoby fizyczne. Warto przypomnieć, że wejście w życie przepisów dotyczących CEIDG poprzedził długi okres vacatio legis, który z jednej strony miał służyć przygotowaniu administracji publicznej do nowych zadań, związanych z funkcjonowaniem CEIDG jako systemu teleinformatycznego ${ }^{4}, \mathrm{z}$ drugiej - okazał się niezbędny do dokonania zmian jeszcze nieobowiązujących przepisów, które ujawniały liczne błędy i niedociagnięcia legislacyjne ${ }^{5}$. Kolejne lata dowiodły, że choć w zamyśle CEIDG miała mieć charakter kompleksowej regulacji, to jednak nie spełniała swej funkcji, tworząc początkowo jedynie zręby systemu ewidencjonowania. Obecnie, co wydaje się już uzasadnione, ale już w ramach wykształconej instytucji, istnieje ciagła potrzeba korygowania i dostosowywania przepisów do zmieniających się warunków prowadzenia działalności gospodarczej, a przede wszystkim do potrzeb przedsiębiorców.

Nie ulega wattpliwości, że rozdział 3 u.s.d.g. był nadmiernie rozbudowany, bez wewnętrznych podziałów, a liczne rozwiązania szczegółowe w nim zawarte

${ }^{1}$ Dz. U. 2018, poz. 647 (dalej jako: ustawa o CEIDGiPIP).

${ }^{2}$ T.jedn.: Dz. U. 2017, poz. 2168 (dalej jako: u.s.d.g.).

${ }^{3}$ Dz. U. 2009, Nr 18, poz. 97.

${ }^{4}$ CEIDG zaczęła obowiązywać z dniem 1 lipca $2011 \mathrm{r}$.

${ }^{5}$ Szerzej na ten temat: A. Trela, Centralna Ewidencja i Informacja o Działalności Gospodarczej - próba oceny nowych rozwiazań prawnych, „Studia Prawa Publicznego” 2013, nr 1, s. $105-132$. 
powodowały, że sama u.s.d.g. zatracała charakter aktu podstawowego mającego określać przede wszystkim prawa przedsiębiorców i ich gwarancje oraz odpowiadajace tym prawom i ich gwarancjom - obowiązi organów administracji publicznej.

Powiedzieć trzeba, że nowelizacja u.s.d.g. wprowadzona ustawą z 19 grudnia 2008 r. ostatecznie zerwała z koncepcją ewidencji, ukształtowanej na gruncie ustawy z 23 grudnia 1988 r. o działalności gospodarczej ${ }^{6}$, prowadzonej początkowo przez terenowe organy administracji państwowej o właściwości szczególnej w sprawach ewidencji działalności gospodarczej stopnia podstawowego, a następnie przez gminy jako zadanie zlecone z zakresu administracji rządowej. Ustawodawca wskazał w uzasadnieniu projektu ustawy z 2008 r. na konieczność usystematyzowania dotychczas obowiąujących przepisów oraz potrzebę wprowadzenia rozwiązań prawnych mających „na celu sprawniejsza i skuteczniejszą obsługę przedsiębiorców, przez m.in. zmniejszenie ilości danych wpisowych, uproszczenie procesu rejestracji i zmiany danych we wpisie w CEIDG, a także ułatwienie zawieszania i wznawiania wykonywania działalności”. Głównym celem CEIDG było jednak stworzenie jednego zbioru, który obejmowałaby wszystkie osoby fizyczne prowadzace działalność gospodarczą na terytorium RP oraz do którego dostęp byłby zapewniony przez platformę informatyczna.

Podejmowanie próby porównywania CEIDG z instytucja uregulowana w ustawie z 23 grudnia 1988 r., opartej na zgoła odmiennej idei, nie może już dzisiaj prowadzić do miarodajnej oceny instytucji. O ile takie badania miały znaczenie tuż po uchwaleniu nowelizacji u.s.d.g. i służyły ukazaniu ewolucji i kierunków zmian przepisów dotyczących ewidencjonowania działalności gospodarczej ${ }^{8}$, to $\mathrm{w}$ dobie zmian, jakie zachodzą w działalności gospodarczej, nowe rozwiązania powinny podlegać ocenie przede wszystkim pod kątem ich adekwatności, komplementarności i kompleksowości wobec zmieniających się uwarunkowań gospodarczych, a także realizacji pewności obrotu gospodarczego i gwarancji praw przedsiębiorców. Taka właśnie myśl stanowi główny cel artykułu, a pytanie o spójność sytemu ewidencjonowania zasługuje na podjęcie próby oceny nowych rozwiązań prawnych.

\section{ZAŁOŻENIA I CELE CEIDG}

1. Ustawodawca pomimo zamierzeń dotyczących likwidacji ewidencji działalności gospodarczej wyrażonych w ustawie z 19 listopada 1999 r. - Prawo

${ }^{6}$ Tekst pierwotny Dz. U. Nr 41, poz. 324.

${ }^{7}$ Uzasadnienie do projektu ustawy o Centralnej Ewidencji i Informacji o Działalności Gospodarczej i Punkcie Informacji dla Przedsiębiorcy - druk nr 2053, <http://www.sejm.gov.pl/Sejm8. nsf/PrzebiegProc.xsp?nr=2053> [dostęp: 17.07.2018].

${ }^{8}$ Szerzej: T. Kocowski, Postępowanie zwiqzane z legalizacja działalności gospodarczej, w: B. Popowska (red.), Swoistość procedur publicznego prawa gospodarczego, Poznań 2013, s. 125-150; M.A. Waligórski, Ewidencja działalności gospodarczej. Uwagi de lege ferenda do projektu ustawy o swobodzie działalności gospodarczej, w: Granice wolności gospodarczej w systemie spotecznej gospodarki rynkowej, Katowice 2004, s. 323. 
działalności gospodarczej ${ }^{9}$ zrezygnował z tego rozwiązania $^{10}$ i ostatecznie opowiedział się za stworzeniem jednolitego, informatycznego systemu ewidencjonowania osób fizycznych prowadzących działalność gospodarcza, zapewniającego szybką wymianę informacji i gwarantującego ich zupełność.

Warto przypomnieć, że określenie „ewidencja” to w myśl słownika języka polskiego „1. spis zawierający dane dotyczące stanu liczbowego i ruchu ludności, spraw lub rzeczy; 2. sporządzanie takich spisów"11. Z kolei w literaturze przyjmuje się, że z ewidencją mamy do czynienia wówczas, gdy rola organu ogranicza się do przyjęcia informacji od podmiotu, bez obowiązku merytorycznej kontroli ich treści. Natomiast w przypadku rejestru organ ma prawo kontrolować treść danych podlegających wpisowi, żądać zmiany ich treści, a także odmówić wpisu ${ }^{12}$. Utrzymanie przez ustawodawcę określenia „ewidencja” oznacza, iż CEIDG ma w dalszym ciagu spełniać rolę spisu, a zadania organów administracji publicznej mają ograniczać się w zasadzie do sprawnego przepływu informacji o przedsiębiorcy pomiędzy różnymi instytucjami prawnymi oraz reagować w sposób władczy w ściśle określonych i wyjątkowych sytuacjach.

CEIDG wedle założeń projektodawcy w 2008 r. miała realizować koncepcję „zero okienka”, polegajacca na wykorzystaniu jednego zintegrowanego formularza i wyeliminowaniu wielu odrębnych wniosków zgłoszeniowych i rejestracyjnych przy podejmowaniu i prowadzeniu działalności gospodarczej. Proponowana nowelizacja nadto miała stanowić wyraz zmiany filozofii w zakresie obowiązków rejestracyjnych przedsiębiorców i dostępu do informacji o innych przedsiębiorcach. Przedsiębiorca miał zgodnie z proponowaną zmianą wypełnić tylko jeden wniosek w celu legalizacji działalności gospodarczej, a reszta obowiązków miała pozostawać w kompetencji administracji publicznej ${ }^{13}$.

Zmianą zaproponowaną w 2008 r. w stosunku do stanu wówczas istniejącego miała być też rezygnacja z lokalnych ewidencji działalności gospodarczej prowadzonych dotychczas w gminach na rzecz centralnej ewidencji prowadzonej w ramach systemu CEIDG. W uzasadnieniu projektu podkreślono, że „platforma informatyczna będzie umożliwiać zakładanie przedsiębiorstwa droga elektroniczna i konieczne w tym celu jest wykorzystanie odpowiednich narzędzi komunikacji między platformą informatyczną a systemami teleinformatycznymi innych organów, identyfikacji użytkowników systemu i uwierzytelniania przesyłanych dokumentów oraz weryfikacji danych wprowadzanych do elektronicznych formularzy" ${ }^{14}$. Wszystkie te usługi miały być dostępne na elektronicznej platformie usług administracji publicznej e-PUAP. Kluczowe znaczenie dla zbudowania mechanizmu wymiany danych między CEIDG

9 Dz. U. Nr 101, poz. 1178.

10 Zob. M. Szydło, Ewidencja działalności gospodarczej jako administracyjny rejestr przedsiębiorców, „Kwartalnik Prawa Publicznego” 2004, nr 1, s. 153-181.

11 Zob. <https://sjp.pl/ewidencja> [dostęp: 19.07.2018].

12 Por. T. Stawecki, Rejestry publiczne. Funkcje instytucji, Warszawa 2005, s. 23.

13 Uzasadnienie do projekt ustawy o zmianie ustawy o swobodzie działalności gospodarczej oraz o zmianie niektórych innych ustaw, druk sejmowy nr 1204, <http://orka.sejm.gov.pl/Druki6ka.nsf/0/A42D601F0FF5DD93C12574EC00410238?OpenDocument> [dostęp: 19.07.2018], s. 3.

14 Ibidem, s. 4. 
a systemami urzędów skarbowych, GUS i ZUS miała mieć tzw. usługa koordynacyjna pozwalająca na komponowanie wielu różnych zasobów w celu utworzenia jednej nowej usługi ${ }^{15}$. W celu umożliwienia przedsiębiorcom realizacji wszystkich procedur związanych z rejestracją i wykonywaniem działalności gospodarczej zakładano utworzenie „dwóch kanałów komunikacji (papierowego i elektronicznego) w relacji obywatel/przedsiębiorca - urzą d"16.

Podstawowym sposobem ewidencjonowania miał być sposób „samorejestracji”, tj. zakładania działalności przez przedsiębiorcę za pomoca podpisu elektronicznego albo profilu zaufanego dostępnego na platformie e-PUAP. Docelowo przewidywano, że w perspektywie pięciu lat od uruchomienia platformy informatycznej nastapi w ogóle rezygnacja ze składania wniosków w formie papierowej. Alternatywnym sposobem ewidencjonowania miało być składanie wniosków „papierowych” w dowolnym urzędzie gminy ${ }^{17}$. W takim trybie pracownik gminy ma za zadanie ustalić tożsamość wnioskodawcy i zweryfikować wniosek, a następnie wprowadzić dane z wniosku do platformy informatycznej. Przyjmowano także, że „rola gminy w odniesieniu do wniosku kończyć się będzie na przesłaniu danych, chyba że wpis będzie wymagać sprostowania lub zostanie wdrożona procedura wykreślenia wpisu niezgodnego z rzeczywistym stanem rzeczy"18.

Omówiona powyżej platforma informatyczna miała pełnić dwie powiązane ze sobą funkcje: ewidencyjna oraz informacyjna, tj. ogólnodostępnej i bezpłatnej bazy danych o innych osobach wykonujących działalność gospodarcza. Przyjęte założenia co do zasady, choć nie od razu zostały zrealizowane, przyniosły wiele korzyści związanych z funkcjami wyznaczonymi CEIDG. Z pewnościa doszło do uproszczenia procedury ewidencyjnej oraz zapewnienia powszechnej dostępności do danych osób fizycznych prowadzacych działalność gospodarcza. Liczne nowelizacje u.s.d.g. w zakresie CEIDG, choć świadcza o niedoskonałościach legislacyjnych, sprawiły, że ustawodawca stopniowo rozwiązywał problemy związane m.in. zakresem danych ujawnianych w CEIDG, w szczególności dotyczących adresu zamieszkania przedsiębiorcy, ujawniania pełnomocnictwa, możliwości składania wniosku o wpis przez pełnomocnika, objęcia wnioskiem wyboru formy opodatkowania, a także wymiany informacji i danych pomiędzy rejestrami publicznymi a CEIDG ${ }^{19}$.

2. Nie ulega wątpliwości, że pewne rozwiazania proceduralne i materialnoprawne $\mathrm{w}$ ramach CEIDG obecnie zostały już ukształtowane i zaakceptowane. Tworza one stabilne ramy prawne organizacji i funkcjonowania CEIDG. Oczywiste jest jednak, że będą pojawiać coraz to nowe problemy, a co za tym idzie - będzie istniała potrzeba udoskonalania tej instytucji prawnej. Konieczność ta legła także u podstaw uchwalenia odrębnej ustawy o CEIDGiPIP. $\mathrm{W}$ ocenie ustawodawcy istniała potrzeba dalszego uproszczenia procedur oraz

\footnotetext{
15 Ibidem, s. 4-5.

16 Ibidem, s. 4.

17 Osobiście albo listem poleconym.

18 Ibidem, s. 4.

19 A. Trela, op. cit., s. 112 i n.
} 
zapewnienia takiej jakości danych zawartych w ewidencji, która będzie miała korzystny wpływ na bezpieczeństwo obrotu gospodarczego ${ }^{20}$. Projekt ustawy wyraźnie wyznaczył kierunek zmian CEIDG przez „umożliwienie udostępniania w CEIDG informacji o udzielonych przez przedsiębiorców pełnomocnictwach oraz ustanowionych prokurentach; dokonanie nowego podziału danych wpisywanych do CEIDG na dane ewidencyjne przedsiębiorcy i dane informacyjne o przedsiębiorcy; wprowadzenie zasady automatycznego wznowienia wykonywania działalności po upływie wskazanego przez przedsiębiorcę okresu zawieszenia; realizację - wynikającej z Prawa przedsiębiorców - zasady możliwości zawieszenia, przez przedsiębiorców - osoby fizyczne, wykonywania działalności gospodarczej na czas nieokreślony (obecnie dopuszczalny okres wynosi co do zasady maksymalnie 24 miesiące); wprowadzenie zasady, że zmiany danych informacyjnych o przedsiębiorcy można dokonać w dowolnym terminie; stworzenie podstawy prawnej do udostępniania ministrowi właściwemu do spraw gospodarki danych gromadzonych przez ZUS i Centralny Rejestru Podmiotów - Krajowej Ewidencji Podatników, co będzie miało istotny wpływ na usprawnienie postępowań administracyjnych toczacych się w ramach CEIDG" ${ }^{21}$.

Zgodzić należy się ze stanowiskiem wyrażonym w uzasadnieniu projektu Prawa przedsiębiorców, że u.s.d.g. była aktem przeregulowanym wieloma „szczegółowymi rozwiązaniami o charakterze technicznym i wykonawczym, które z powodzeniem - i z pożytkiem dla większej przejrzystości i czytelności tego ogólnego aktu prawnego - mogłyby być unormowane w ustawach odrębnych, przy zachowaniu w tej ustawie głównej jedynie podstawowych zrębów uregulowania określonych instytucji prawnych ${ }^{22}$.

Zaznaczyć warto, że CEIDG prowadzi w systemie teleinformatycznym minister właściwy do spraw gospodarki, a jej zadaniem jest zgodnie z brzmieniem art. 2 ust. 2 ustawy o CEIDGiPIP: 1) ewidencjonowanie przedsiębiorców będących osobami fizycznymi; 2) udostępnianie informacji o przedsiębiorcach i innych podmiotach w zakresie wskazanym w ustawie; 3) udostępnianie informacji o zakresie i terminie zmian we wpisach do CEIDG oraz w informacjach i danych udostępnianych w CEIDG, a także o wprowadzającym te zmiany podmiocie; 4) umożliwienie wglądu do danych bezpłatnie udostępnianych przez Centralną Informację Krajowego Rejestru Sądowego; 5) udostępnianie informacji o ustanowionym pełnomocniku lub prokurencie, w tym o zakresie udzielonego pełnomocnictwa lub o rodzaju i sposobie wykonywania prokury.

Wszystkie z tych zadań są ciagle udoskonalane przez wprowadzanie nowych i usprawnienie istniejących rozwiązań prawnych. Co istotne, nowa ustawa o CEIDGiPIP wprowadza systematykę wewnętrzną dającą większa przejrzystość oraz uporządkowanie instytucji i procedur wpisujacych się w określone powyżej zadania.

${ }^{20}$ Uzasadnienie do projektu ustawy o CEIDGiPIP.

${ }^{21}$ Ibidem, s. 1-2.

${ }^{22}$ Uzasadnienie do rządowego projektu ustawy - Prawo Przedsiębiorców, druk sejmowy $\mathrm{nr}$ 2051, <http://www.sejm.gov.pl/Sejm8.nsf/druk.xsp?documentId=9E761CF9B6B03CBCC12581E10059DD88> [dostęp: 17.07.2018]. 


\section{DZIAŁALNOŚĆ NIEEWIDENCJONOWANA}

Ustawa z 6 marca 2018 r. - Prawo przedsiębiorców ${ }^{23}$ w art. 5 ust. 1 wprowadziła szczególny rodzaj działalności, której nie uznaje za działalność gospodarczą i która nie wymaga ewidencjonowania (tzw. działalność nieewidencjonowana). Jest to działalność wykonywana przez osobę fizyczna, której przychód należny z tej działalności nie przekracza w żadnym miesiącu 50\% kwoty minimalnego wynagrodzenia (o którym mowa w ustawie z 10 października 2002 r. o minimalnym wynagrodzeniu za pracę ${ }^{24}$ ) i która w okresie ostatnich 60 miesięcy nie wykonywała działalności gospodarczej ${ }^{25}$. Osoba wykonująca taką działalność może jednak złożyć wniosek o wpis do CEIDG, a działalność ta staje się działalnościa gospodarczą z dniem określonym we wniosku. Natomiast jeżeli przychód należny z działalności niepodlegającej wpisowi do CEIDG przekroczy w danym miesiącu wysokość określoną powyżej, działalność ta staje się działalnościa gospodarcza, począwszy od dnia, w którym nastapiło przekroczenie wysokości. W takim przypadku osoba wykonująca taką działalność składa wniosek o wpis do CEIDG w terminie 7 dni od dnia, w którym nastapiło przekroczenie wysokości 50\% kwoty minimalnego wynagrodzenia.

Wobec tego, że działalność określona w art. 5 ust. 1 Pr.przeds. nie jest działalnościa gospodarcza, to tym samym podmiot ją wykonujący nie jest przedsiębiorcą w rozumieniu Pr.przeds. Może się jednak nim stać z własnej inicjatywy - z dniem wskazanym we wniosku do CEIDG z wszystkimi konsekwencjami publicznoprawnymi albo z mocy prawa - z dniem, w którym nastapiło przekroczenie wysokości 50\% kwoty minimalnego wynagrodzenia.

Z przepisu art. 195 ustawy z 6 marca 2018 r. Przepisy wprowadzające ustawę - Prawo przedsiębiorców oraz inne ustawy dotyczące działalności gospodarczej ${ }^{26}$ wynika, że art. 5 ust. 1 Pr.przeds. odnosi się również do działalności wykonywanej przez osoby, które w okresie 12 miesięcy przed dniem wejścia w życie Pr.przeds. nie były wpisane do CEIDG lub których wpis został wykreślony z CEIDG wcześniej niż 12 miesięcy przed dniem wejścia w życie Pr.przeds. (o której mowa w art. 1 ust. 1), nawet jeżeli w okresie ostatnich 60 miesięcy przed dniem wejścia w życie tej ustawy wykonywały działalność gospodarcza.

Regulacja dotycząca działalności nieewidencjonowanej nie ma z kolei zastosowania do działalności wykonywanej w ramach umowy spółki cywilnej, a także do działalności wymagającej uzyskania koncesji, zezwolenia albo wpisu do rejestru działalności regulowanej (art. 44 ust. 3 Pr.przeds.).

${ }^{23}$ Dz. U. 2018, poz. 646 (dalej jako: Pr.przeds.).

${ }^{24}$ T.jedn.: Dz. U. 2017, poz. 847 ze zm.

${ }^{25}$ R. Blicharz, Kilka uwag na temat przepisów ogólnych projektu ustawy Prawo przedsiębiorców, w: K. Kiczka, T. Kocowski, W. Małecki (red.), Praworzqdność, decentralizacja, przedsiębiorczość, Wrocław 2018, s. 432, dokonuje wyróżnienia przesłanki podmiotowej, przychodowej oraz tzw. negatywnej związanej z nieprowadzeniem działalności gospodarczej.

${ }^{26}$ Dz. U. 2018, poz. 650. 
Jak stanowi art. 4 ust. 3 Pr.przeds., zasady podejmowania, wykonywania i zakończenia działalności gospodarczej przez osoby zagraniczne określaja odrębne przepisy, tj. przepisy ustawy z 6 marca 2018 r. o zasadach uczestnictwa przedsiębiorców zagranicznych i innych osób zagranicznych w obrocie gospodarczym na terytorium Rzeczypospolitej ${ }^{27}$. Skoro art. 4 ust. 1 ustawy o zasadach uczestnictwa przedsiębiorców zagranicznych stanowi, że osoby zagraniczne z państw członkowskich moga podejmować i wykonywać działalność gospodarczą na terytorium Rzeczypospolitej Polskiej na takich samych zasadach jak obywatele polscy i podobne zasady obowiązują wobec osób zagranicznych posiadających „status specjalny”, to uznać należy, że wobec tych podmiotów (osób fizycznych) także została przewidziana możliwość wykonywania działalności nieewidencjonowanej.

Rozwiąanie wprowadzone przez ustawodawcę w art. 5 ust. 1 Pr.przeds. ma istotne znaczenie z punktu widzenia definicji ustawowej działalności gospodarczej, przez która rozumie się zorganizowaną działalność zarobkowa, wykonywaną we własnym imieniu i w sposób ciagły. Dotychczas cel zarobkowy działalności gospodarczej był pojmowany jako zamiar osiagnięcia zarobku bez względu na to, czy zysk zostanie osiagnięty ${ }^{28}$. Tym bardziej nie miało znaczenia, w jakiej wysokości zostanie osiagnięty „zarobek”. Wyłączenie z działalności gospodarczej tzw. działalności „niskoprzychodowej” ${ }^{29}$ sprawia obecnie, że rozmiar działalności (przekraczającej określony przychód) stanowi kryterium decydujące o zakwalifikowaniu danej aktywności do działalności gospodarczej $^{30}$. Dodatkową wątpliwość powoduje okoliczność, że działalność „niskoprzychodowa", jak nazywa ją projektodawca, z dniem wskazanym przez przedsiębiorcę we wniosku do CEIDG staje się działalnością gospodarcza, a podmiot ja prowadzący nabywa status przedsiębiorcy. Nie oznacza to jednak, by wpis do CEIDG miał inny charakter aniżeli czynność materialno-techniczna. W tym przypadku bowiem to nie od wpisu w CEIDG zależeć będzie, czy dana działalność zakwalifikowana będzie jako działalność gospodarcza, a od woli osoby prowadzącej działalność gospodarczą. W literaturze słusznie zwraca się uwagę, że „działalności nieewidencjonowanej nie towarzyszy obowiązek, lecz prawo do złożenia wniosku o stosowny wpis do rejestru” ${ }^{31}$.

W praktycznych komentarzach do Pr.przeds. wskazuje się, że powyższe rozwiązanie było „ukłonem wobec osób, które chciałyby przetestować nowy pomysł na biznes" 32 . Głównie rozwiązanie to dotyczyć ma działalności okazjonalnej, dorywczej, której koszt prowadzenia w postaci składek ZUS znaczaco przewyższał przychód. Istnieje jednak obawa, że wprowadzenie tej instytucji

${ }^{27}$ Dz. U. 2018, poz. 649.

28 Szerzej: K. Strzyczkowski, Prawo gospodarcze publiczne, Warszawa 2009, s. 218; M. Szydło, Swoboda działalności gospodarczej, Warszawa 2005, s. 36.

${ }_{29}$ Uzasadnienie do projektu ustawy Prawo przedsiębiorcy - druk sejmowy nr 2051.

30 Por. R. Blicharz, op. cit., s. 435-436.

${ }^{31}$ M. Biliński, A. Żurawik, Zasady ogólne publicznego prawa gospodarczego, w: System prawa administracyjnego, t. 8A, red. R. Hauser, Z. Niewiadomski, A. Wróbel, Warszawa 2018, s. 507.

${ }^{32}$ L. Jaworski, Działalność ewidencjonowana i ulga na start pomoże rozkręcić firmę, „Dziennik Gazeta Prawna” z 3 kwietnia 2018, nr 65(4715), s. C2. 
może prowadzić do krycia dochodów wobec niedookreślenia możliwości weryfikacji źródeł dochodu osób wykonujących „działalność nierejestrową" ${ }^{33}$.

Konsekwencją spełnienia warunków działalności nieewidencjonowanej jest jej wyłączenie z zakresu wszelkich przepisów dotyczących działalności gospodarczej. Dodatkowo „skoro taka forma aktywności nie będzie działalnościa gospodarczą, to również nie będzie stanowiła tytułu do ubezpieczeń społecznych i ubezpieczenia zdrowotnego. Osoba fizyczna, która będzie wykonywała działalność nieewidencjonowana, nie będzie miała obowiązku zgłoszenia siebie do ubezpieczeń społecznych i do ubezpieczenia zdrowotnego albo do ubezpieczenia zdrowotnego" ${ }^{34}$. Pamiętać jednak należy, że ustawa z 11 marca 2004 r. o podatku od towarów i usług ${ }^{35}$ posiada własną definicję działalności gospodarczej. Obejmuje ona również osoby, które będą - zgodnie z Pr.przeds. - prowadziły działalność nieewidencjonowana. W konsekwencji osoby te uznane będą za podatników podatku VAT pod warunkiem, że będą spełniały warunki ustawowe. Ustawa o VAT w art. 113 przewiduje zwolnienie podmiotowe dla osób nieprzekraczających limitu przychodów, tj. kwoty 200000 zł. Z kolei z art. 109 ust. 1 ustawy o VAT wynika, że podatnicy, u których sprzedaż jest zwolniona od podatku na podstawie art. 113 ust. 1 i 9, sa obowiązani prowadzić ewidencję sprzedaży za dany dzień, nie później jednak niż przed dokonaniem sprzedaży w dniu następnym. Na podmiotach prowadzących działalność nieewidencjonowaną ciąży także obowiązek rozliczania się z podatku dochodowego zgodnie z art. 20 ust. 1ba ustawy z 26 lipca 1991 r. o podatku dochodowym od osób fizycznych ${ }^{36}$ - za przychody z innych źródeł uznaje on przychody osiagane z działalności, o której mowa w art. 5 ust. 1 Pr.przeds.

Już z uzasadnienia projektu Pr.przeds. wynika, że celem ustawodawcy było uznanie, że działalność nieewidencjonowana nie ma być uznawana za działalność gospodarczą ${ }^{37}$. Oczywiste jest, że rozwiązanie to modyfikuje definicję działalności gospodarczej, wyłączając z niej działalność „niskoprzychodową, której legalne prowadzenie połączone z obciążeniami publicznoprawnymi było po prostu nieopłacalne. Sprawia także, że dotychczasowe postrzeganie działalności prowadzonej w ramach „szarej strefy” na małą skalę staje się prawnie zalegalizowane. $\mathrm{W}$ ten sposób wyeliminowany zostaje problem zgłaszania do CEIDG działalności prowadzonej np. przez studentów udzielających korepetycji czy osób wykonujących drobne naprawy przedmiotów gospodarstwa domowego, które nie przekraczaja kryterium przychodowego.

${ }^{33}$ B. Kotowicz, M. Słaby, Utatwienia dla przedsiębiorców - próba oceny nowych rozwiazań prawnych, w: Ustawa $z$ 6.3.2018 r. - Prawo przedsiębiorców - analiza i ocena najważniejszych przepisów, red. M. Sieradzka, Dodatek Specjalny do „Monitora Prawniczego” 2018, nr 13, s. 42.

${ }^{34}$ Zob. <https://poradnikprzedsiebiorcy.pl/-dzialalnosc-nieewidencjonowana-nowosc-w-konstytucji-biznesu> [dostęp: 20.07.2018].

${ }_{35}$ T.jedn.: Dz. U. 2017, poz. 1221 ze zm.

${ }^{36}$ T.jedn.: Dz. U. 2018, poz. 200 ze zm.

${ }^{37}$ Uzasadnienie rządowego projektu ustawy - Prawo przedsiębiorców. 


\section{GŁÓWNE KIERUNKI ZMIAN CEIDG}

Jak wskazano wcześniej, uchwalenie ustawy o CEIDGiPIP miało charakter porządkowy, ale i udoskonalajacy tę instytucję. Analizując przepisy, zauważyć można, że ustawa o CEIDGiPIP zachowuje w pełni procedurę dokonywania wpisu, z tym tylko, że dokonuje podziału na tzw. dane ewidencyjne i dane informacyjne o przedsiębiorcy. Dane ewidencyjne to: 1) imię i nazwisko przedsiębiorcy, numer PESEL, o ile taki posiada, oraz data urodzenia, o ile nie posiada numeru PESEL; 2) dodatkowe określenia, które przedsiębiorca włącza do firmy, o ile przedsiębiorca takich używa; 3) numer identyfikacyjny REGON przedsiębiorcy, o ile taki posiada; 4) numer identyfikacji podatkowej (NIP) przedsiębiorcy, o ile taki posiada, oraz informacje o jego unieważnieniu lub uchyleniu; 5) informacja o obywatelstwie przedsiębiorcy; 6) adres do doręczeń oraz - jeżeli przedsiębiorca takie miejsce posiada - adres stałego miejsca wykonywania działalności gospodarczej; dane dotyczące adresu sa zgodne z oznaczeniami kodowymi przyjętymi w krajowym rejestrze urzędowym podziału terytorialnego kraju, o ile to w danym przypadku możliwe; 7) inne niż wymienione w pkt 6 dane kontaktowe przedsiębiorcy, w szczególności adres poczty elektronicznej, adres strony internetowej, numer telefonu, o ile dane te zostały zgłoszone przez przedsiębiorcę we wniosku o wpis do CEIDG; 8) przedmiot wykonywanej działalności gospodarczej według Polskiej Klasyfikacji Działalności (PKD) na poziomie podklasy, w tym jeden przedmiot przeważającej działalności. Zmiany danych ewidencyjnych powinna być dokonywana w terminie 7 dni od jej zajścia.

Dane informacyjne zostały z kolei określone w art. 5 ust. 2 Pr.przeds. i sa to m.in. data rozpoczęcia działalności gospodarczej, data zawieszenia i wznowienia działalności gospodarczej, informacja o wykreśleniu z CEIDG, informacja o zakazie prowadzenia działalności gospodarczej. W ocenie projektodawcy dane informacyjne przedsiębiorca będzie mógł natomiast zmienić w każdym czasie. Są to dane, których aktualność nie ma bezpośredniego wpływu na innych uczestników obrotu gospodarczego. Organy państwa posiadają jednocześnie uprawnienie weryfikacji tych danych na podstawie odrębnych przepisów prawa $^{38}$.

Za właściwe uznać należy rozwiązanie przewidziane w art. 10 ust. 3 ustawy o CEIDGiPIP pozwalające w przypadku składania wniosków o zmianę w CEIDG na umieszczanie ograniczonej ilości danych. Dotychczas obowiązujące przepisy wymagały, by wniosek (z wyjątkiem wniosku o zawieszenie działalności gospodarczej) zawierał wszystkie dane. Niewatpliwie dotychczasowy obowiązek był zbędny i utrudniał przedsiębiorcom jego wypełnienie ${ }^{39}$. Ustawodawca przewidział, że w przypadku wniosku papierowego rozwiązanie to polegać będzie na zmniejszeniu liczby rubryk formularza do wypełnienia przez przedsiębiorcę. Natomiast „organ gminy, który przekształca wniosek

\footnotetext{
${ }^{38}$ Uzasadnienie projektu ustawy o CEIDGiPIP, s. 7.

39 Ibidem, s. 8.
} 
na wersję elektroniczna, będzie musiał uzupełnić tylko dane wskazane przez przedsiębiorcę. Pozostała część wniosku zostanie "prewypełniona" przez system CEIDG" ${ }^{40}$.

Nie ulega zmianie także zakres podmiotów objętych wpisem do CEIDG, niemniej jednak ustawodawca uznał za niezbędne doprecyzowanie, że osoby wykonujące działalność wytwórczą w rolnictwie nie podlegają wpisowi do CEIDG. To rozwiązanie, w świetle ugruntowanych poglądów doktryny i orzecznictwa, wydaje się, że jest całkowicie zbędnym powtórzeniem ${ }^{41}$ oraz że wynika to już wprost z przepisów Pr.przeds.

Pozytywna zmiana jest natomiast wprowadzenie do ustawy o CEIDGiPIP rozdziału zatytułowanego: Wpis do CEIDG informacji o zawieszeniu i wznowieniu wykonywania działalności gospodarczej. Nowa regulacja wychodzi naprzeciw oczekiwaniom przedsiębiorców, aby nie wskazywać maksymalnego okresu zawieszenia działalności gospodarczej. Jest to konsekwencja regulacji art. 23 ust. 1 Pr.przeds. Przedsiębiorca obecnie ma prawo złożyć wniosek o wpis informacji o zawieszeniu wykonywania działalności gospodarczej bez wskazywania okresu, na jaki to zawieszenie następuje. Jeżeli jednak przedsiębiorca zdecyduje się wskazać okres, na jaki zawiesza wykonywanie działalności gospodarczej, wznowienie nastapi automatycznie z upływem tego okresu.

Pozytywnie należy także ocenić regulację zawartą w rozdz. 6: Zasady publikowania w CEIDG informacji o pełnomocnikach i prokurentach. Zaznaczyć należy, że ustawą z 13 maja 2011 r. postanowiono uruchomić w ramach CEIDG tzw. rejestr pełnomocnictw ${ }^{42}$. Na podstawie art. 25 ust. 1 pkt 11 u.s.d.g. wpisowi do CEIDG podlegały dane pełnomocnika upoważnionego do prowadzenia spraw przedsiębiorcy, wraz ze wskazaniem zakresu spraw, które obejmuje pełnomocnictwo, o ile przedsiębiorca go udzielił i zgłosił informację o jego udzieleniu we wniosku o wpis do CEIDG. Przepisy dotyczące wpisu pełnomocnika do CEIDG obwiązywały od 1 lipca 2011 r., a dopiero z dniem 1 stycznia 2012 r. uruchomiono rejestr pełnomocnictw, stanowiacy integralną część CEIDG.

W założeniu informacja o udzielonych pełnomocnictwach miała uprościć stosunki prywatnoprawne między przedsiębiorcami, jak również stosunki przedsiębiorców z organami administracji publicznej.

Zgodnie z przepisami u.s.d.g. rejestr pełnomocnictw miał istotne znaczenie $\mathrm{w}$ postępowaniach przed organem administracji publicznej. Wobec ujawnienia pełnomocnictwa w CEIDG nie stosowało się przepisu art. $33 \S 3$ Kodeksu postępowania administracyjnego ${ }^{43}$. W takim przypadku organ administracji

40 Ibidem, s. 9.

${ }^{41} \mathrm{~W}$ szczególności R. Budzinowski, Status prawny rolnika (zagadnienia wybrane), „Ruch Prawniczy, Ekonomiczny i Socjologiczny” 64, 2002, z. 3, s. 111-120, oraz uchwała SN z 26 lutego 2015 r., III CZP 108/14, <http://www.sn.pl/sites/orzecznictwo/Orzeczenia3/III\%20CZP\%20108-14. pdf $>$ [dostęp 17.07.2018].

42 Ustawa z 13 maja 2011 r. o zmianie ustawy o swobodzie działalności gospodarczej oraz o zmianie niektórych innych ustaw, Dz. U. Nr 131, poz. 764.

${ }^{43}$ Ustawa z 14 czerwca 1960 r., t.jedn.: Dz. U. 2017, poz. 1257 ze zm. 
publicznej z urzędu potwierdzał w CEIDG upoważnienie pełnomocnika do prowadzenia sprawy w imieniu przedsiębiorcy. Obecnie ustawodawca uznał, że dla usprawnienia obrotu gospodarczego, w szczególności przy podejmowaniu działań na odległość, konieczne jest rozszerzenia funkcjonalności CEIDG w zakresie elektronicznego udzielania pełnomocnictwa. Taka forma ma stanowić alternatywę dla występujących powszechnie w obrocie prawnym i gospodarczym tradycyjnych pełnomocnictw udzielonych w formie pisemnej. Za pomocą systemu teleinformatycznego CEIDG będzie możliwe szybkie i sprawne opublikowanie udzielonego pełnomocnictwa, wyłączając przy tym konieczność posługiwania się każdorazowo jego papierowa wersja ${ }^{44}$. Ustawodawca przyjął, że opublikowanie przez przedsiębiorcę w CEIDG informacji o pełnomocniku/ prokurencie ${ }^{45}$ będzie równoznaczne $\mathrm{z}$ udzieleniem pełnomocnictwa na piśmie. Wraz z wnioskiem o opublikowanie za pośrednictwem systemu teleinformatycznego CEIDG informacji przedsiębiorca jest obowiązany złożyć oświadczenie, że pełnomocnik lub prokurent przyjął odpowiednio pełnomocnictwo lub prokurę. Oświadczenie to składa się pod rygorem odpowiedzialności karnej. Przepisów dotyczących zasad publikowania informacji o pełnomocnikach i prokurentach nie stosuje się $\mathrm{w}$ sprawach prowadzonych na podstawie przepisów ustawy z 29 sierpnia $1997 \mathrm{r}$. - Ordynacja podatkowa ${ }^{46}$ oraz ustawy z 16 listopada 2016 r. o Krajowej Administracji Skarbowej ${ }^{47}$.

Za właściwe uznać należy także wyodrębnienie w rozdziale 4 przepisów dotyczących wpisywania do CEIDG informacji z urzędu. Przepisy zawarte w tym rozdziale ukazują nie tylko szereg powiązań pomiędzy różnymi systemami rejestracji a CEIDG, ale przede wszystkim określają zakres zadań i kompetencji spoczywajacych na innych organach administracji publicznej i instytucjach, które są zobowiązane do przekazywania danych ewidencyjnych i informacyjnych o przedsiębiorcy. Jeszcze przed wejściem w życie CEIDG ${ }^{48} \mathrm{w} 2011$ r., jak i tuż po $^{49}$ zwracałam uwagę na brak kompleksowej regulacji w tym zakresie i konieczność wprowadzenia zmian, które usprawniłyby wymianę danych pomiędzy rejestrami publicznymi, a także pozwoliły na precyzyjne określenie kompetencji poszczególnych organów i instytucji gwarantujących wiarygodność CEIDG.

Co istotne, ustawodawca zdecydował również, że przekazywanie danych i informacji do CEIDG oraz przekazywanie danych i informacji z CEIDG odbywać się będzie nie za pośrednictwem e-PUAP, ale za pośrednictwem systemu teleinformatycznego CEIDG lub za pośrednictwem innego, zintegrowanego z nim systemu teleinformatycznego, w szczególności za pośrednictwem syste-

${ }^{44}$ Uzasadnienie projektu ustawy o CEIDGiPIP, s. 15.

${ }^{45}$ Możliwość ustanowienia prokury dla przedsiębiorcy wpisanego do CEIDG przewiduje art. $109^{1} \S 1$ ustawy z 23 kwietnia 1964 r. - Kodeks cywilny, t.jedn.: Dz. U. 2017, poz. 459 ze zm.

${ }^{46}$ T.jedn.: Dz. U. 2017, poz. 201 ze zm.

47 T.jedn.: Dz. U. 2018, poz. 508 ze zm.

${ }^{48}$ Opinia dotycząca CEIDG przygotowana w ramach współpracy Zespołu ds. Finansów Publicznych, Gospodarki i Rozwoju Przedsiębiorczości KPPO - niepublikowana.

${ }^{49}$ A. Trela, Założenia i cele reformy Ewidencji Działalności Gospodarczej, w: Prawo i administracja, red. K. Wojtczak, Piła 2008, s. 62; eadem, Centralna..., s. 112 i n. 
mu Punktu Informacji dla Przedsiębiorcy. Rozwiązanie to podyktowane było znikomym korzystaniem z platformy e-PUAP przy dokonywaniu wpisów do CEIDG.

\section{WNIOSKI}

Nowa ustawa o CEIDGiPIP bez wątpienia realizuje postulat przejrzystości i udoskonalania rozwiązań prawnych w celu zapewnienia większej gwarancji obrotu gospodarczego. Za właściwe uznać należy wyodrębnienie przepisów dotyczących CEIDG w ramach nowego aktu prawnego, z wewnętrzną systematyką porządkująca procedurę dokonywania wpisu w CEIDG, zmiany wpisu oraz jego wykreślenia. Usystematyzowanie przepisów i usprawnienie procedur CEIDG ukazuje tę instytucję jako pewien system (zbiór) kompleksowy z wyszczególnionymi zadaniami organów administracji publicznej, który ma zapewnić szybka wymianę informacji o przedsiębiorcy. Zmiany wprowadzone do CEIDG ocenić należy co do zasady pozytywnie: przynoszą rozwiązania, które z jednej strony mają być przejrzyste dla przedsiębiorcy i mają ułatwiać prowadzenie działalności gospodarczej, z drugiej - porządkują zadania organów administracji i instytucji publicznych, na których spoczywa obowiązek przekazywania danych o przedsiębiorcy.

Analizowane przepisy ustawy o CEIDGiPIP potwierdzaja założenia projektodawcy o konieczności ulepszenia i większej funkcjonalizacji instytucji CEIDG i właśnie z tego punktu widzenia powinny podlegać ocenie. Ustawodawcy nie chodziło bowiem o gruntowną reformę systemu ewidencjonowania, a o usprawnienie instytucji, która trwale wpisała się w porządek prawny. Przede wszystkim pozytywnie należy ocenić te zmiany, które uproszczają procedury oraz ograniczają obowiązki przedsiębiorców związane z ujawnianiem informacji w CEIDG przez niepotrzebne ich powielanie w sytuacji, gdy zostały już one umieszczone w systemie. Istniała także potrzeba doprecyzowania zadań organów administracji publicznej oraz podmiotów i instytucji w zakresie gromadzenia i przekazywania informacji o przedsiębiorcy do CEIDG. Ustawa o CEIDGiPIP odpowiada także na potrzeby przedsiębiorców dotyczące okresu zawieszania działalności gospodarczej. W odniesieniu do osób fizycznych ustawodawca nie wprowadza maksymalnego okresu zwieszenia i pozostawia to $\mathrm{w}$ gestii przedsiębiorcy.

Nie bez znaczenia było też podjęcie próby prawnej regulacji działalności niskoprzychodowej. Od lat zastanawiano się, czy tego rodzaju działalność, kosztowna z racji obciążeń publicznoprawnych, powinna podlegać ewidencjonowaniu. Względy racjonalne wymogły potrzebę wprowadzenia tzw. działalności nieewidencjonowanej.

Jak wspomniano powyżej, ciagła potrzeba dostosowywania przepisów CEIDG do potrzeb obrotu gospodarczego istnieje nadal. Wprowadzanie nowych instytucji prawnych związanych z prowadzeniem działalności gospodarczej przez osoby fizyczne wymagać będzie dalszych zmian w ustawie o CEIDGiPIP. Przykładem takiej zmiany jest z pewnością nowelizacja usta- 
wy o CEIDGiPIP dokonana ustawą z 5 lipca 2018 r. o zarządzie sukcesyjnym przedsiębiorstwem osoby fizycznej50. Ustawa o zarządzie sukcesyjnym reguluje zasady tymczasowego zarządzania przedsiębiorstwem po śmierci przedsiębiorcy, który we własnym imieniu wykonywał działalność gospodarczą na podstawie wpisu do CEIDG, oraz kontynuowania działalności gospodarczej wykonywanej z wykorzystaniem tego przedsiębiorstwa.

dr Anna Trela

Uniwersytet im. Adama Mickiewicza w Poznaniu

atrela@amu.edu.pl

https://orcid.org/0000-0002-2014-5579

\title{
CENTRAL REGISTER AND INFORMATION ON ECONOMIC ACTIVITY IN THE LIGHT OF NEW LEGAL REGULATIONS
}

\begin{abstract}
Summary
The solutions concerning the Central Register and Information on Economic Activity (CEIDG) regulated in the Act of 6 March 2018 on the Central Register and Information on Economic Activity and the Information Point for Entrepreneurs are analysed. The starting point of the analysis is the assumptions set out in the rationale for the draft act. Next, the changes introduced by the new act in terms of these assumptions, in particular with regard to the ordering of regulations, the division of data contained in the CEIDG, their exchange and facilitations for entrepreneurs are assessed. The authoress also analyses the activities that are not subject to entry in the CEIDG (not registered) introduced by the provisions of the Act of 6 March 2018: Law on Entrepreneurs.
\end{abstract}

${ }^{50}$ Dz. U. 2018, poz. 1629. 
